\title{
Pengaruh Hedging, Financial Lease dan Sales Growth terhadap Agresivitas Pajak
}

\author{
Winda Sangata Ramadhani ${ }^{\mathrm{a},}{ }^{,}$, Dedik Nur Triyanto ${ }^{\mathrm{b}}$ and Kurnia ${ }^{\mathrm{c}}$ \\ ${ }^{a}$ Fakultas Ekonomi dan Bisnis, Telkom University, windasangata27@gmail.com, Indonesia \\ ${ }^{\mathrm{b}}$ Fakultas Ekonomi dan Bisnis, Telkom University, dedik.triyanto@gmail.com, Indonesia \\ ${ }^{\mathrm{c}}$ Fakultas Ekonomi dan Bisnis, Telkom University, akukurnia@telkomuniversity.ac.id, Indonesia
}

\begin{abstract}
The purpose of this study aims to analyze the influence of hedging, financial lease, and sales growth on tax aggressiveness. This study uses secondary data derived from financial statements of mining companies listed on the Indonesia Stock Exchange in the 2011-2018 period. Tax aggressiveness is measured using the Effective Tax Rate proxy, Hedging is measured using Absolute Value of the fair value of the hedge divided by the total assets of the previous year, Financial leas e is measured by a dummy variable by observing companies that use or do not use financial leases to obtain fixed assets, and Sales growth is measured by comparing the current year's sales minus the previous year's sales against the previous year's sales. Total sample obtained from the reduction using the purposive sampling technique of 32 samples. The data analysis model used panel data regression analysis, descriptive statistical analysis, and classic assumption test. The results of this study are hedging, financial lease and sales growth have a simultaneous effect on tax aggressiveness. While partially hedging does not affect on tax aggressiveness, the financial lease has a positive effect on tax aggressiveness and sales growth has a negative affect on tax aggressiveness.
\end{abstract}

Keywords: agresivitas pajak, hedging, financial lease, sales growth

*Corresponding author. E-mail: windasangata27@gmail.com 


\section{Pendahuluan}

Setiap negara memiliki rencana pengembangan nasional dengan maksud untuk meningkatkan kesejahteraan dan kemakmuran rakyatnya, seperti pembangunan infrastruktur dan berbagai fasilitas publik lainnya. Berkaitan dengan pembangunan nasional tentunya tidak terlepas dari biaya yang dikeluarkan negara dalam merealisasikan program tersebut. Sumber pendanaan pembangunan nasional bersumber dari APBN, yang sebagian besar ditopang oleh penerimaan pajak dan sisanya dari penerimaan non pajak. Dalam hal ini, peran pajak dalam perekonomian di Indonesia sangatlah penting, selain itu pajak merupakan salah satu penerimaan negara yang bersumber dari pungutan wajib pada rakyat yang bersifat memaksa serta ketentuan pelaksanaan dan pemungutannya tercantum di dalam UndangUndang Dasar 1945 pasal 23A disebutkan bahwa pajak dan pungutan lain yang bersifat mamaksa untuk keperluan negara diatur dengan undangundang. Akan tetapi pada kenyataannya realisasi penerimaan perpajakan belum memenuhi target yang telah ditetapkan. Realisasi penerimaan pajak dari tahun 2011-2018 berkisar antara 83\% sampai dengan 94\% (kemenkeu, 2019).

Tidak tercapainya target penerimaan pajak salah satu faktornya adalah dari tindakan agresivitas pajak oleh wajib pajak yang tidak patuh dalam menjalankan kebijakan pemungutan pajak yang telah diatur dalam Peraturan Perpajakan. Tindakan penghindaran pajak agresif dapat disebabkan karena Indonesia menerapkan sistem pemungutan pajak Self Assessment System, dimana pada sistem tersebut wajib pajak diberikan kewenangan untuk menghitung sendiri jumlah pajak yang terutang (Mardiasmo, 2016). Sehingga, tidak menutup kemungkinan bahwa wajib pajak akan berusaha menyetorkan pajak sekecil mungkin guna mengecilkan tax expense yang seharusnya dibayarkan kepada negara menggunakan cara agresivitas pajak.

Menurut Lanis \& Richardson (2012), agresivitas pajak dapat dinilai dari dua cara, yakni dilakukan dengan cara legal dan ilegal.. Penelitian terdahulu yang meneliti mengenai agresivitas pajak salah satunya dengan menggunakan hedging. Oktavia \& Martani (2013) menyebutkan bahwa pengguna derivatif (tanpa membedakan tujuan untuk hedging maupun spekulasi) mempunyai tingkat agresivitas lebih tinggi dibandingkan non pengguna derivatif. Sedangkan pada penelitian Nurhandono \& Firmansyah (2017) diperoleh hasil tidak ada hubungan yang diantara hedging dan agresivitas pajak.

Selain itu terdapat penelitian lain yang meneliti agresivitas pajak dengan menggunakan financial lease. Menurut Setiani (2016) financial lease memiliki pengarh positif terhadap tax avoidance. Sedangkan Rahman \& Tjetje (2019) mengungkapkan bahwa ada pengaruh negatif financial lease terhadap penghindaran pajak, dan Sari (2019) menyatakan financial lease tidak berpengaruh terhadap penghindaran pajak.

Agresivitas pajak juga dapat dipengaruhi oleh sales growth perusahan. Dewinta \& Setiawan (2016) menyatakan bahwa pertumbuhan pejualan mempunyai pengaruh positif terhadap penghindaran pajak. Hasil penelitian Na, Park \& Cho (2017) mengungkapkan bahwa sales growth berpengaruh positif terhadap agresivitas pajak. Penelitian tersebut bertolak belakang dengan hasil penelitian Hidayat (2018) yaitu pertumbuhan penjualan memiliki pengaruh negatif terhadap tax avoidance serta menurut Swingly \& Sukartha (2015) yang mengungkapkan sales growth tidak memiliki pengaruh terhadap penghindaran pajak.

Berdasarkan latar belakang penelitian, maka penelitian ini akan meneliti lebih lanjut mengenai pengaruh hedging, financial lease dan sales growth terhadap agresivitas pajak pada perusahaan pertambangan periode 2011-2018. Penelitian ini diharapkan mampu memberikan bayangan terkait berbagai hal yang kemungkinan dapat mendorong perusahaan untuk melakukan tindakan agresivitas pajak.

\section{Tinjauan Literatur dan Hipotesis}

\section{Agency Theory}

Agency theory pertama kali diuraikan oleh Jensen dan Meckling (1976) yang menjelaskan korelasi antara pemegang saham (principal) serta manajemen (agent) dalam menjalankan kewajibannya dengan melakukan penyerahan kewenangan kepada agen pada proses pengambilan keputusan. Dalam agresivitas pajak, manajemen mempunyai keinginan untuk merekayasa jumlah laba perusahaan dengan tujuan untuk mengurangi besarnya beban pajak yang tertanggung oleh perusahaan. Tindakan tersebut dapat terjadi karena terdapat perbedaan informasi antara manajemen (agent) selaku pembuat laporan keuangan serta yang mengoperasikan praktik akuntansi dengan principal selaku pemakai 
financial statement. Tindakan tersebut bertolak belakang dengan keinginan investor yang tidak berkenan dengan dilakukannya tindakan pajak agresif suatu perusahaan terdeteksi melakukan tindakan agresivitas pajak bertentangan dengan hukum maka perusahaan akan memiliki permasalahan hukum yang dapat berdampak pada kelangsungan usaha sekaligus, sebab apabila dapat merusak reputasi perusahaan.

\section{Agresivitas Pajak}

Frank et al (2009) mendefinisikan agresivitas pajak sebagai aktivitas yang memiliki tujuan untuk memanipulasi besarnya taxable income dengan melakukan kegiatan tax planning baik secara legal (tax avoidance) ataupun illegal (tax evasion). Tujuan dilakukannya agresivias pajak oleh perusahaan adalah untuk meminimalkan tax expense yang ditanggung oleh perusahaan. Meskipun tidak semua tindakan tax planning melawan hukum, namun banyaknya celah kelemahan dari peraturan perpajakan banyak dimanfaatkan oleh pihak manajemen perusaahaan dalam upaya meringankan beban pajak.

\section{Hedging}

Menurut Subramanyam \& Wild (2010:356), Lindung nilai (hedging) merupakan perjanjian yang dilakukan antara suatu pihak dengan pihak yang lainnya yang memiliki tujuan untuk melindungi perusahaan dari risiko pasar. Lindung nilai yang dilakukan perusahaan diharapkan dapat melindungi perusahaan dari peluang terjadinya kerugian yang diakibatkan dari perubahan tingkat suku bunga, nilai tukar dan perubahan harga komoditas utama.

\section{Financial Lease}

Berdasakan PSAK No 73 Tahun 2020 tentang Sewa, Financial Lease yaitu sewa yang mengalihkan secara substantial seluruh risiko dan manfaat yang terkait dengan kepemilikan aset pendasar. Salah satu keuntungan perusahaan dalam melakukan financial lease yaitu pada akhir masa sewa selesai perusahaan dapat membeli aset yang bersangkutan dengan membayar nilai sisa aset tersebut.

\section{Sales Growth}

Pertumbuhan penjualan (sales growth) yaitu merujuk pada kenaikan penjualan antara periode berjalan dan periode sebelumnya dalam persentase (Carvalho dan Costa, 2014). Pertumbuhan penjualan yang terus meningkat menandakan bahwa suatu perusahaan mengalami keberhasilan dalam menjalankan usahanya. Kenaikan pada penjualan diharapkan mampu menghasilkan tambahan aliran kas masuk yang dapat mempengaruhi jumlah aset yang dimiliki perusahaan.

\section{Pengembangan Hipotesis}

\section{Pengaruh hedging terhadap agresivitas pajak}

Perbedaan keinginan diantara manajemen
perusahaan dengan investor menyebabkan
munculnya perbedaan informasi pada saat
pengungkapan informasi laporan keuangan. Pihak
manajemen yang memiliki otoritas pada proses
penyusunan laporan keuangan mempunyai lebih
banyak informasi daripada investor, hal ini
dimanfaatkan oleh pihak manajemen untuk
melakukan tindakan agresivitas pajak melalui
transaksi lindung nilai. Berdasarkan hasil penelitian
Donohoe (2011) yang mengungkapkan bahwa
derivatif keuangan yang bukan untuk diperdagangan
berpengaruh positif terhadap agresivitas pajak.
Oktavia dan Martani (2013) menyatakan bahwa
pengguna financial derivatives (tanpa membedakan
tujuan spekulasi maupun hedging) memiliki
pengaruh positif terhadap agresivitas pajak.
$\mathrm{H}_{1}:$ Hedging berpengaruh positif terhadap agresivitas
pajak

\section{Pengaruh financial lease terhadap agresivitas pajak}

Financial lease merupakan salah satu alternatif yang dipilih perusahaan dalam memperoleh aset tetapnya dibandingkan dengan membeli secara tunai. Dengan melakukan perjanjian financial lease dapat lebih menghemat biaya yang dikeluarkan oleh perusahaan dibandingkan dengan melakukan pembelian aset tetap secara tunai. Pembayaran sewa diperhitungkan menjadi biaya yang dapat dijadikan pengurang taxable income sehingga beban pajak 
yang tertanggung menjadi lebih kecil, artinya financial lease mempunyai pengaruh positif terhadap agresivitas pajak. Pernyataan tersebut sesuai dengan penelitian Setiani (2016) yaitu sewa guna usaha dengan hak opsi memiliki pengaruh positif terhadap penghindaran pajak.

$\mathrm{H}_{2}$ : Financial Lease berpengaruh positif terhadap agresivitas pajak.

\section{Pengaruh sales growth terhadap agresivitas pajak}

Pertumbuhan penjualan adalah rasio tingkat perubahan kenaikan penjualan dari suatu periode ke periode lainnya yang merupakan gambaran dari kesuksesan suatu perusahaan dari periode sebelumnya serta dapat digunakan untuk mengestimasi penjualan untuk periode selanjutnya. Jumlah laba yang akan diterima perusahaan dapat diprediksi dari besarnya pertumbuhan penjualan. Apabila penjualan perusahaan mengalami kenaikan kemungkinan laba perusahaan juga akan meningkat, maka dari itu akan mendorong dilakukannya tindakan agresivitas pajak oleh pihak manajemen perusahaan dikarenakan besarnya keuntungan yang diperoleh perusahaan akan menyebabkaan beban pajak yang ditanggung perusahaan menjadi besar. Berdasarkan teori tersebut dapat disimpulkan bahwa sales growth mempunyai pengaruh positif terhadap agresivitas pajak. Pernyataan tersebut sejalan dengan hasil penelitian yang dilakukan oleh Dewinta \& Setiawan ( 2016) yang menyatakan bahwa semakin tinggi pertumbuhan penjualan berdampak pada meningkatnya tax avoidance. Pendapat tersebut diperkuat dengan hasil penelitian lain yaitu pertumbuhan penjualan berpengaruh positif terhadap tax avoidance (Nabila \& Fikri, 2018).

$\mathrm{H}_{3}$ : Sales growth berpengaruh positif terhadap agresivitas pajak

\section{Metode Penelitian}

\section{Jenis Penelitian}

Jenis penelitian yang digunakan dalam studi ini yaitu kuantitatif dengan memanfaatkan teknik analisis deskriptif untuk mengetahui hubungan antar variabel yang berbeda. Penelitian ini menggunakan metode analisis regresi data panel sebagai alat untuk mengolah dan menganalisis data, karena data yang dipakai adalah perpaduan dari data time series dan data cross section (Sujarweni, 2015:1). Metode analisis regresi data panel berguna untuk melihat ada dan tidaknya pengaruh dari variabel independen yang digunakan pada variabel dependen sekaligus dengan arah pengaruhnya.

Penelitian ini menggunakan sampel perusahaan pertambangan yang tercatat di BEI tahun 2011-2018. Teknik pengambilan sampel yang dipakai yaitu purposive sampling dengan memilih sampel secara acak sesuai kriteria yang telah ditentukan. Kriteria tersebut yaitu antara lain :

1. Perusahaan pertambangan yang tercatat di BEI tahun 2011-2018.

2. Perusahaan pertambangan yang konsisten menerbitkan financial statement dari tahun 2011-2018.

3. Perusahaan pertambangan yang memiliki laba positif tahun 2011-2018.

4. Perusahaan yang terindikasi melakukan derivatif keuangan dengan tujuan lindung nilai.

Data yang digunakan pada penelitian ini merupakan jenis data sekunder berupa laporan keuangan perusahaan pertambangan yang tercatat di BEI dari periode 2011-2018. Data dapat diperoleh dari laporan keuangan yang dapat diakses melalui website resmi Bursa Efek Indonesia (www.idx.co.id) maupun website masing-masing perusahaan.

\section{Variabel Terikat}

Variabel terikat yang digunakan pada penelitian ini ialah agresivitas pajak. Menurut Frank et al (2009), agresivitas pajak merupakan aktivitas yang mempunyai tujuan untuk memanipulasi besarnya taxable income dengan melakukan tindakan tax planning baik secara legal (tax avoidance) ataupun illegal (tax evasion). Proxy yang dipakai untuk menilai agresivitas pajak pada studi ini yaitu dengan Effective Tax Rates (ETR). ETR dinilai dengan menggunakan proxy model Lanis \& Richardson (2012) yang paling banyak diterapkan pada penelitian terdahulu :

$\mathrm{ETR}=\frac{\text { Total Tax Expense }}{\text { Pretax Income }}$

Variabel Bebas

Hedging

Hedging atau Lindung nilai merupakan kontrak yang dilakukan antara suatu pihak dengan pihak yang lainnya yang memiliki tujuan untuk melindungi perusahaan dari risiko pasar (Subramanyan dan Wild, 
2010). Untuk mengukur hedging dengan proxy yang digunakan (Donohoe, 2012) dalam mengukur financial derivative yaitu :

FVHED $=$ Absolute value of fv of hedge

$$
\text { Total asset } \mathrm{t}-1
$$

\section{Financial Lease}

Menurut PSAK No 73 Tahun 2020 tentang Sewa, Financial Leasing yaitu sewa yang mengalihkan secara substantial seluruh risiko dan manfaat yang terkait dengan kepemilikan asset pendasar. Dalam penelitian ini, untuk mengukur financial lease adalah menggunakan variabel dummy yaitu apabila perusahaan dalam memperoleh sebagian asset tetap diperoleh dengan menggunakan financial lease diberi nilai 1 (satu) dan apabila perusahaan tidak menggunakan financial lease dalam mendapatkan asset tetap akan diberikan nilai 0 (nol).

\section{Sales Growth}

Sales Growth merupakan rasio yang mengukur besarnya peningkatan penjualan antara periode berjalan dengan periode sebelumnya yang merupakan cerminan keberhasilan usaha suatu perusahaan periode sebelumnya (Hidayat, 2018). Proksi untuk mengukur sales growth pada penelitian ini dapat dihitung dengan rumus :

$$
\text { Sales Growth }=\frac{\text { Sales }_{t}-\text { Sales }_{\mathrm{t}-1}}{\text { Sales }_{\mathrm{t}-1}}
$$

\section{Model Analisis Regresi Data Panel}

Persamaan data panel pada penelitian ini dapat dituliskan dalam bentuk berikut ini :

$$
Y i t=\beta_{0}+\beta_{1} H E D_{i t}+\beta_{2} F L_{i t}+\beta_{3} S G_{i t}+\text { cit }
$$

Keterangan :

$$
\begin{aligned}
& \text { Yit }=\text { Agresivitas pajak perusahaan } \mathrm{i} \\
& \text { dalam kurun waktu } t \\
& \beta_{0} \quad=\text { Intersep atau konstanta } \\
& \beta 1, \beta 2, \beta 3=\text { Koefisien regresi } \\
& H E D_{i t} \quad=\text { Hedging perusahaan i dalam kurun } \\
& \text { waktu } \mathrm{t} \\
& F L_{i t} \quad=\text { Financial Lease perusahaan i } \\
& \text { dalam kurun waktu } \mathrm{t} \\
& S G_{i t} \quad=\quad \text { Sales Growth i dalam kurun waktu } \\
& \text { sit }=\text { Variabel gangguan (error) unit } \mathrm{i} \\
& \text { dalam kurun waktu } t
\end{aligned}
$$

Dalam penelitian menggunakan data panel terdapat tiga metode pendekatan estimasi untuk menentukan metode terbaik yang digunakan, yaitu model common effect, model fixed effect dan model random effect (Sriyana, 2014).

\section{Hasil dan Pembahasan}

Objek penelitian ini merupakan perusahaan pertambangan yang terdaftar di BEI tahun 20112018. Metode yang digunakan pada penentuan sampel menggunakan purposive sampling berdasarkan kriteria pemilihan sampel yang telah ditetapkan. Berikut merupakan hasil dari penentuan sampel perusahaan yang akan digunakan dalam proses penelitian yang diuraikan di tabel 1 .

Tabel 1

Hasil Seleksi Sampel Penelitian

\begin{tabular}{llc}
\hline No & \multicolumn{3}{c}{ Kriteria Sampel } & Jumlah \\
\hline $1 . \quad \begin{array}{l}\text { Perusahaan pertambangan yang tercatat di } \\
\text { BEI tahun 2011-2018. }\end{array}$ \\
$\begin{array}{l}\text { Perusahaan pertambangan yang tidak } \\
\text { konsisten menerbitkan financial statement } \\
\text { dari tahun 2011-2018. }\end{array}$ \\
$\begin{array}{l}\text { Perusahaan pertambangan yang tidak } \\
\text { memiliki laba positif tahun 2011-2018. }\end{array}$ \\
$\begin{array}{l}\text { Perusahaan yang tidak terindikasi } \\
\text { melakukan derivatif keuangan dengan } \\
\text { tujuan lindung nilai }\end{array}$ \\
$\begin{array}{l}\text { Total sampel perusahaan } \\
\text { Jumlah periode penelitian }\end{array}$ \\
Jumlah data yang yang dijadikan sampel \\
\hline Sumber : Data yang telah diolah penulis, 2020
\end{tabular}

\section{Analisis Deskriptif}

Berikut ini merupakan penjabaran hasil analisis deskriptif yaitu :

Tabel 2

Hasil Analisis Deskriptif

\begin{tabular}{lcccc}
\hline & $E T R$ & $H E D$ & $F L$ & $S G$ \\
\hline Mean & 0,306384 & 0,006553 & 0.562500 & 0,228918 \\
Maximum & 0,547400 & 0,040500 & 1.000000 & 3,647000 \\
Minimum & $-1,13370$ & 0,000000 & 0.000000 & $-0,278200$ \\
Std. Dev. & 0,275587 & 0,009806 & 0.504016 & 0,670073 \\
$\mathrm{~N}$ & 32 & 32 & 32 & 32 \\
\hline Sumber $:$ Data yang diolah, 2020 &
\end{tabular}

Berdasarkan hasil analisis deskriptif tabel 2 dapat ditarik kesimpulan bahwa nilai rata-rata ETR perusahaan pertambangan tahun 2011-2018 sebesar 0,306384 lebih tinggi dari standar deviasinya sebesar 0,275587 . Ini berarti nilai ETR pada penelitian ini 
tidak bervariasi (cenderung berkelompok). Nilai maksimum ETR yaitu 0,54740 sedangkan nilai minimum ETR yaitu $-1,13370$.

Nilai mean $H E D$ perusahaan pertambangan tahun 2011-2018 senilai 0,006553 lebih rendah dari standar deviasinya yaitu 0,009806 . Artinya nilai $H E D$ dalam penelitian ini bervariasi bersifat fluktuatif atau menyebar. Nilai maksimum $H E D$ yaitu 0,040500 sedangkan nilai minimumnya yaitu 0 .

Nilai mean $F L$ perusahaan pertambangan tahun 2011-2018 yakni 0,562500 lebih tinggi dari standar deviasinya senilai 0,504016 . Artinya nilai $F L$ pada penelitian ini tidak bervariasi (cenderung berkelompok). Nilai maximum dari FL yakni 1 sedangkan nilai minimum adalah 0 .

Nilai rata-rata dari $S G$ perusahaan pertambangan tahun 2011-2018 senilai 0,228918 lebih rendah dari nilai standar deviasinya yakni 0,670073 . Ini berarti nilai $S G$ pada penelitian ini bervariasi atau bersifat fluktuatif atau menyebar. Nilai maksimum $S G$ sebesar 3,647000 sedangkan nilai minimumnya sebesar $-0,278200$.

\section{Uji Asumsi Klasik}

Uji asumsi klasik yang dipakai pada studi ini yakni uji multikoliniearitas dan uji heteroskedastisitas dengan tujuan untuk menilai suatu data yang digunakan dalam penelitian apakah terjadi atau tidaknya gejala multikoliniearitas serta gejala heteroskedastisitas. Berikut merupakan hasil dari uji multikoliniearitas:

Tabel 3

Hasil Uji Multikolinieritas

\begin{tabular}{cccc}
\hline Keterangan & $H E D$ & $F L$ & $S G$ \\
\hline$H E D$ & 1.000000 & 0.108625 & -0.008525 \\
$F L$ & 0.108625 & 1.000000 & -0.120973 \\
$S G$ & -0.008525 & -0.120973 & 1.000000 \\
\hline \multicolumn{2}{l}{ Sumber : Data output Eviews 9,2020 }
\end{tabular}

Hasil uji multikolinieritas dari tabel 3 menunjukan hasil analisis nilai korelasi variabel hedging (HED), financial lease (FL), dan sales growth (SG) berturutturut sebesar 0,108625 dan -0,008525. Dari hasil tersebut menunjukan bahwa nilai korelasi $<0.90$ yang berarti tidak terdapat hubungan antar variabel bebas atau tidak ada gejala multikoliniearitas.

Berikut merupakan tabel hasil pengujian heteroskedastisitas:
Tabel 4

Hasil Uji Heterokedasitas

Dependent Variable: RESABS

Sample: 20112018

Periods included: 8

Cross-sections included: 4

Total panel (balanced) observations: 32

\begin{tabular}{crrrr}
\hline \hline Variable & Coefficient & Std.Error & t-Statistic & Prob. \\
\hline \hline C & 8.847303 & 1.762282 & 5.020366 & 0.0000 \\
HED & -1.317597 & 1.091082 & -1.207606 & 0.2373 \\
$F L$ & -1.282813 & 2.138519 & -0.599860 & 0.5534 \\
SG & 0.007432 & 0.015991 & 0.464774 & 0.6457 \\
\hline Sumber $:$ Data output Eviews 9,2020 & &
\end{tabular}

Tabel 4 menunjukkan bahwa nilai probabilitas dari setiap variabel tidak ada yang lebih rendah dari 0,05 atau seluruh variabel bebas mempnyai probabilitas $>$ 0.05 , artinya pada studi ini tidak terjadi gejala heteroskedastisitas.

\section{Analisis Regresi Data Panel}

Penelitian ini menggunakan teknik analisis regresi data panel yang merupakan perpaduan antara data runtun waktu serta data silang. Dalam menggunakan teknik analisis regresi data panel terdapat tiga pemilihan metode estimasi yang dipakai yakni model common effects, fixed effects, dan random effects (Sriyana, 2014). Pemilihan model estimasi yang tepat dapat dilakukan dengan melakukan uji chow, uji hausman dan uji lagrange multiplier.

Untuk mengetahui model estimasi terbaik yang akan dipilih pada penelitian ini, maka dilakukan uji chow dan uji lagrange multiplier yang hasilnya akan dipaparkan di tabel 5 dan 6 berikut ini :

Tabel 5

Hasil Uji Chow

Redundant Fixed Effects Tests

Equation: Untitled

Test cross-section fixed effects

\begin{tabular}{lcrc}
\hline \hline Effects Test & Statistic & d.f. & Prob. \\
\hline \hline $\begin{array}{l}\text { Cross-section F } \\
\begin{array}{l}\text { Cross-section Chi- } \\
\text { square }\end{array}\end{array}$ & 0.734282 & $(3,25)$ & 0.5414 \\
\hline
\end{tabular}

Sumber: Data output Eviews 9, 2020 
Tabel 5 menunjukkan hasil nilai probabilitas $C h i$ square yakni senilai $0,4398>\alpha=0,05$ yang artinya $\mathrm{H}_{0}$ diterima, maka model common effects lebih tepat untuk digunakan dalam penelitian. Dikarenakan hasil pengujian dengan uji chow menunjukan bahwa model common effects yang lebih tepat untuk digunakan, maka selanjutkan dilakukan uji lagrange multiplier untuk membandingkan model common effects dengan model random effects.

\section{Tabel 6 \\ Hasil Uji Lagrange Multiplier}

Lagrange Multiplier Tests for Random Effects Null hypotheses: No effects

Alternative hypotheses: Two-sided (BreuschPagan) and one-sided (all others) alternatives

\begin{tabular}{|c|c|c|c|}
\hline \multicolumn{4}{|c|}{ Test Hypothesis } \\
\hline \multirow{3}{*}{$\begin{array}{l}\text { Breusch- } \\
\text { Pagan }\end{array}$} & $\begin{array}{l}\text { Cross- } \\
\text { section }\end{array}$ & Time & Both \\
\hline & 0.833552 & 0.742737 & 1.576289 \\
\hline & $(0.3612)$ & $(0.3888)$ & $(0.2093)$ \\
\hline
\end{tabular}

Sumber : Data output Eviews 9, 2020

Berdasarkan tabel 6, diketahui nilai probability Breusch-Pagan yakni 0,3612 >0,05 $\left(\mathrm{H}_{0}\right.$ diterima $)$ artinya model common effects lebih sesuai untuk dipilih pada penelitian ini. Berikut merupakan hasil dari common effects model:

Tabel 7

Hasil Common Effects Model

Dependent Variable: ETR

Method: Panel Least Squares

\begin{tabular}{ccccc}
\hline \hline Variable & Coefficient & Std. Error & t-Statistic & Prob. \\
\hline \hline C & 35.15465 & 2.991952 & 11.74974 & 0.0000 \\
HED & -2.360167 & 1.852407 & -1.274108 & 0.2131 \\
$F L$ & 9.753823 & 3.630716 & 2.686473 & 0.0120 \\
$S G$ & -0.369393 & 0.027149 & -13.60616 & 0.0000 \\
\hline \hline R-squared & & 0.879780 & & \\
Adjusted R-squared & 0.866899 & & \\
Prob(F-statistic) & 0.000000 & &
\end{tabular}

Sumber : Data output Eviews 9, 2020

Berdasarkan tabel 7, diperoleh persamaan regresi data panel yang dapat dirumuskan sebagai berikut :

Agresivitas pajak $=35,15465-2,360167$ HED + 9,753823FL-0,369393 SG+
Dimana :

$$
\begin{array}{ll}
\text { ETR } & =\text { Agresivitas Pajak } \\
H E D & =\text { Hedging } \\
F L & =\text { Financial Lease } \\
S G & =\text { Sales Growth } \\
\varepsilon & =\text { Error term }
\end{array}
$$

Dari persamaan tersebut dapat diuraikan beberapa hal yaitu :

1. Konstanta dari persamaan tersebut senilai 35,15465 , berarti apabila variabel hedging, financial lease dan sales growth memiliki nilai 0 , maka tindakan pajak agresif yang dilakukan yakni 35,15465 .

2. Nilai koefisien hedging sebesar -2.360167 , hal ini menunjukkan bahwa jika variabel hedging bertambah sejumlah 1 satuan dan variabel yang lain bernilai tetap maka akan menurunkan agresivitas pajak sebanyak 2.360167 satuan.

3. Nilai koefisien financial lease sebesar 9.753823 artinya jika variabel financial lease bertambah sejumlah 1 satuan dan diasumsikan variabel yang lain bernilai tetap, maka agresivitas pajak akan meningkat sejumlah 9.753823 satuan.

4. Nilai koefisien sales growth yaitu -0.369393 , hal ini menunjukkan bahwa apabila variabel sales growth bertambah senilai 1 satuan dan diasumsikan variabel lain bernilai tetap, maka agresivitas pajak akan menurun sejumlah 0.369393 satuan.

Tabel 7 menunjukkan bahwa nilai Adjusted $R$ squared dari uji koefisien determinasi dalam penelitian ini senilai 0,866899 atau sebesar 86,68\%. Hal ini berarti hedging, financial lease dan sales growth mampu menjelaskan tindakan pajak agresif pada perusahaan pertambangan yang tercatat di BEI tahun $2011-2018$ sebesar $86,68 \%$ sedangkan sisanya yaitu sebesar $13,32 \%$ diuraikan oleh variabel lain diluar penelitian ini.

Hasil uji simultan (uji statistik F) dari tabel 7 menunjukkan hasil nilai Prob(F-statistic) lebih kecil dari 0,05 yakni sebesar 0,00000. Hal ini menunjukkan bahwa hedging, financial lease dan sales growth secara bersama-sama memberikan pengaruh secara simultan terhadap agresivitas pajak pada perusahaan pertambangan periode 2011-2018. Dilihat dari hasil uji parsial (uji t) pada tabel 7 dapat ditarik kesimpulan sebagai berikut:

\section{$\mathrm{H}_{1}$ : Hedging berpengaruh positif terhadap} agresivitas pajak 
Probability value hedging (HED) senilai 0,2131 > dari 0,05 dengan nilai koefisien $-2,360167$ yang berarti secara parsial hedging tidak mempunyai pengaruh terhadap agresivitas pajak sehingga hipotesis pertama ditolak.

\section{$\mathrm{H}_{2}$ :Financial Lease berpengaruh positif terhadap agresivitas pajak}

Probability value financial lease (FL) yaitu $0,0120<$ dari 0,05 dengan nilai koefisien positif senilai 9,753823 artinya secara parsial financial lease berpengaruh positif terhadap agresivitas pajak sehingga hipotesis kedua diterima.

\section{$\mathrm{H}_{3}$ : Sales Growth berpengaruh positif terhadap agresivitas pajak}

Probability value sales growth (SG) yaitu 0,0000 $<$ dari 0,05 dan nilai koefisien negatif senilai 0,369393, artinya secara parsial sales growth berpengaruh kearah negatif terhadap agresivitas pajak ini berarti hipotesis ketiga ditolak.

\section{Pembahasan}

\section{Pengaruh Hedging terhadap Agresivitas Pajak}

Berdasarkan hasil uji parsial (uji t) membuktikan bahwa hedging tidak berpengaruh terhadap agresivitas pajak, ini berarti hipotesis pertama yang mengungkapkan hedging berpengaruh positif terhadap agresivitas pajak ditolak. Hasil pengujian analisis deskriptif pada perusahaan pertambangan yang memiliki nilai hedging dibawah rata-rata terindikasi tidak melakukan agresivitas pajak sebanyak 20 sampel dari 21 sampel, dan nilai hedging diatas rata-rata yang terindikasi tidak meakukan agresivitas pajak sebanyak 8 dari 11 sampel, total sampel 32 sampel. Sehingga dapat disimpulkan bahwa mayoritas perusahaan pertambangan yang memiliki nilai hedging diatas dan dibawah rata-rata tidak melakukan agresivitas pajak, sehingga hedging tidak berpengaruh terhadap tindakan agresivitas pajak. Selain itu, PSAK 55 menentukan beberapa syarat agar transaksi derivatif dapat ditetapkan sebagai instrumen lindung nilai, sehingga tidak semua transaksi derivatif digunakan untuk melakukan lindung nilai namun bisa juga untuk tujuan spekulatif. Sampel yang digunakan pada penelitian ini hanya sebatas pada perusahaan yang mengungkapkan nilai wajar dari transaksi derivatif yang digunakan untuk lindung nilai. Hasil penelitian ini tidak sejalan dengan penelitiaan yang dilakukan oleh Donohoe (2011) yang menyatakan bahwa hedging memiliki pengaruh signifikan dengan agresivitas pajak. Selain itu Oktavia \& Martani (2013) juga menyatakan pendapat yang sama bahwa tingkat penggunaan derivatif (tanpa membedakan tujuan spekulatif maupun lindung nilai) memiliki pengaruh terhadap tingkat agresivitas pajak.

\section{Pengaruh Financial Lease terhadap Agresivitas Pajak}

Hasil uji secara parsial (uji t) menyatakan bahwa financial lease memiliki pengaruh positif terhadap agresivitas pajak, artinya semakin tinggi perusahaan melakukan financial lease maka semakin tinggi tingkat agresivitas pajak yang dilakukan oleh perusahaan. Berdasarkan hasil penelitian analisis deskriptif yaitu sebanyak 18 sampel perusahaan atau sebesar 56,25\% sampel perusahaan menggunakan financial lease dari total sampel 32 sampel perusahaan yang digunakan. Biaya yang dibayarkan sehubungan dengan perolehan fixed asset selama masa sewa dapat dijadikan sebagai pengurang penghasilan bruto. Biaya yang digunakan pada saat melakukan financial lease lebih tinggi dikarena biaya yang dapat dijadikan beban merupakan total seluruh biaya lease berserta biaya bunganya, hal ini dapat berpengaruh pada besarnya taxable income menjadi kecil sehingga tax expense perusahaan juga menjadi kecil (Ulhusna,2013). Hasil penelitian ini sesuai dengan penelitian Setiani (2016) yang mengungkapkan financial lease berpengaruh positif terhadap tax avoidance.

\section{Pengaruh Sales Growth terhadap Agresivitas Pajak}

Bersumber pada hasil uji parsial (uji t), membuktikan bahwa sales growth berpengaruh negatif terhadap agresivitas pajak. Artinya, hipotesis ketiga yang mengungkapkan sales growth memiliki pengaruh positif terhadap agresivitas pajak ditolak. Sales growth yaitu gambaran peningkatan penjualan dari suatu periode ke periode selanjutnya. Karena hasil dari pengujian parsial menyatakan bahwa pertumbuhan penjualan mempunyai pengaruh negatif terhadap agresivitas pajak, artinya apabila sales growth mengalami peningkatan maka tindakan agresivitas pajak semakin berkurang. Berdasarkan hasil pengujian analisis deskriptif nilai sales growth diatas rata-rata hanya dimiliki oleh 11 sampel perusahaan dan yang terindikasi tidak melakukan tindakan agresivitas pajak sebanyak 9 sampel, sedangkan yang memiliki nilai sales growth dibawah rata-rata (cenderung mengalami penurunan 
penjualan) sebanyak 21 sampel dan hanya 2 sampel yang melakukan tindakan agresivitas pajak. Perusahaan yang mempunyai pertumbuhan penjualan yang tinggi menggambarkan perusahaan mempunyai kinerja yang baik selain itu laba yang dihasilkan juga mengalami peningkatan dan perusahaan mampu membayar pajak sesuai dengan besar pajak yang tertanggung. Selain itu pengawasan terhadap perusahaan dengan tingkat penjualan yang tinggi juga lebih diperketat terutama dalam hal perpajakan. Hasil penelitian ini tidak sesuai dengan studi yang dilakukan oleh Dewinta \& Setiawan (2016) serta Nabila \& Fikri (2018) yang mengungkapkan pertumbuhan penjualan memiliki pengaruh positif terhadap tax avoidance.

\section{Penutup}

\section{Kesimpulan}

Berdasarkan hasil pengujian mengenai pengaruh hedging, financial lease, dan sales growth terhadap agresivitas pajak pada perusahaan pertambangan tahun 2011-2018 dapat disimpulkan beberapa hal antara lain :

1. Hedging tidak memiliki pengaruh terhadap agresivitas pajak, hal ini berarti semakin besar transaksi hedging yang dilakukan tidak memiliki pengaruh terhadap agresivitas pajak.

2. Financial lease berpengaruh positif terhadap agresivitas pajak, artinya terdapat keterkaitan satu arah antara financial lease dan agresivitas pajak. Oleh karena itu, jika financial lease yang dilakukan perusahaan semakin tinggi, maka agresivitas pajak perusahaan juga semakin tinggi.

3. Sales growth berpengaruh negatif terhadap agresivitas pajak, artinya hubungan antara sales growth dengan agresivitas pajak tidak searah. Sehingga apabila sales growth mengalami kenaikan, maka tindakan agresivitas pajak semakin rendah atau bahkan mungkin tidak melakukan agresivitas pajak.

\section{Keterbatasan}

Berdasarkan penelitian yang telah dilakukan, terdapat beberapa keterbatasan yaitu :

1. Perusahaan yang dijadikan sampel hanya sebatas pada perusahaan sektor pertambangan yang menggunakan kebijakan lindung nilai.
2. Variabel independen yang digunakan dalam studi ini sebanyak 3 variabel, masih terdapat variabel lainnya yang kemungkinan dapat mempengaruhi agresivitas pajak.

Saran

Berikut saran dari penelitian ini yaitu :

1. Menggunakan sampel perusahaan pada sektor lain yang tercatat di BEI.

2. Menambahkan jumlah variabel bebas dalam penelitian selanjutnya yang kemungkinan memiliki pengaruh terhadap agresivitas pajak.

3. Menggunakan proxy pengukuran lain untuk mengukur financial lease selain dengan menggunakan variabel dummy.

\section{References}

Carvalho, L \& T. Costa. (2014). Smal and Medium Entriprise (SMEs) and Competitiveness : An Empirical Study. Management Studies, 88-95.

Dewan Standar Keuangan (2020). PSAK No. 73 Tentang Sewa. Ikatan Akuntansi Indonesia.

Donohoe, M. P. (2011.). Financial Derivatives in Corporate Tax Avoidance : an Empirical Examination of New Users . Working Paper.

Donohoe, M. P. (2012). Financial Derivatives in Corporate Tax Avoidance : Why, How and Who? Working Paper, University of Illinois at Urbana-Champaign.

Frank, Mary Margaret \& L. J. (2009). Tax Reporting Aggressiveness and Its Relation to Aggresive Financial Reporting. The Accounting Review, 467-496.

Hidayat, W. W. (2018). Pengaruh Profitabilitas, Leverage dan Pertumbuhan Penjualan terhadap Penghindaran Pajak . Jurnal Riset Manajemen dan Bisnis (JRMB) Fakultas Ekonomi UNIAT, 19-26.

Jensen, M. C. \& Meckling (1976). Theory of The Firm : Manajerial Behavior, Agency Cost and Ownership Structure. Journal of Financial Economics 3, 305-360.

Lanis, Roman \& G. Richardson (2012). Corporate Social Responsibility and Tax Aggressiveness : An empirical analysis. Journal Accounting Public Policy, 86-108.

Mardiasmo. (2016). Perpajakan. Yogyakarta: Andi.

Na, Hyung Jong, Sung Ook Park \& Soo Ah Cho. (2017). Firm Age, Sales Growth and Tax Aggressiveness : Focus on SMEs. Penelitian Pajak Vol. 17 No.4 Forum Penelitian Pajak Korea. 
Nurhandono, Furqon \& Amrie Firmansyah (2017). Lindung Nilai, Financial Laverage, Manajemen Laba dan Agresivitas Pajak. Jurnal Media Riset Akuntansi, Auditing \& Informasi, 31-52.

Oktavia dan Dwi Martani (2013). Tingkat Pengungkapan dan Penggunaan Derivatif Keuangan dalam Aktivitas Penghindaran Pajak. Jurnal Akuntansi dan Keuangan Indonesia, 129-146.

Rahman, Fatahul \& N. F. Tjetje (2019). Analisis Faktor-Faktor Yang Mempengaruhi Tax Avoidance. Jurnal Akuntansi Multidimensi (JAMDI).

Sari, L. I. (2019). Analisis Pengaruh Return On Assets, Debt To Equity Ratio, Debt To Assets Ratio, Current Ratio dan Financial Lease Terhadap Tax Avoidance Pada Perusahaan Manufaktur Yang Terdaftar Di Bursa Efek Indonesia Periode 2012-2017. Jurnal Sains, Akuntansi dan Manajemen .

Setiani, C. J. (2016). Analisis Faktor-Faktor Yang Mempengaruhi Tax Avoidance. Skirpsi Universitas Lampung.
Setiawan, Putu Ery dan Ida Ayu Rosa Dewinta. (2016). Pengaruh Ukuran Perusahaan, Umur Perusahaan, Profitabilitas, Leverage dan Pertumbuhan Penjualan terhadap Tax Avoidance. E-Jurnal Akuntansi, 1584-1613.

Sriyana, J. (2014). Metode Regresi Data Panel. Yogyakarta: Ekonisia.

Subramanyam dan Wild. (2010). Analisis Laporan Keuangan. Jakarta: Salemba Empat.

Sujarweni, V. Wiratna. (2015). Metodologi Penelitian Bisnis \& Ekonomi. Yogyakarta: Pustaka Baru Press.

Swingly, Calvin dan I Made Sukartha (2015). Pengaruh Karakter Eksekutif, Komite Audit, Ukuran Perusahaan, Leverage dan Sales Growth pada Tax Avoidance. E-Jurnal Akuntansi, 47-62.

Ulhusna, D. A. (2013). Analisis Perencanaan Pajak atas Perolehan Alat Berat Serta Pengaruhnya Terhadap Laba Kena Pajak dan PPh Terutang. Skripsi, Universitas Lampung. 